\title{
Description of medication adherence in hypertensive respondents at Mandalika Mataram elderly social centre
}

\author{
Anna Pradiningsih, Dzun Haryadi Ittiqo, Neti Puput Arianti \\ Faculty of Health Sciences, University of Muhammadiyah, Mataram, Indonesia
}

Keywords
Adherence
Elderly
Hypertension
Social centers
Correspondence
Anna Pradiningsih
Department of Pharmacology and Clinical Pharmacy
Faculty of Health Sciences
University of Muhammadiyah Mataram
Mataram 83127
Indonesia
annapradiningsih@gmail.com

Keywords

Hypertension

Correspondence

Anna Pradiningsih

harmacy

culty of Health Sciences

Mataram 83127

annapradiningsih@gmail.com

\begin{abstract}
Introduction: Elderly people are at high risk of non-adherence to hypertensive therapy due to changes in body function and ageing processes. Aim: The purpose of this study is to explore medication adherence among hypertensive respondents at the Mandalika Mataram NTB Elderly Social Centre. Methods: This study is descriptive observational with a purposive sampling technic. The sample consisted of 30 respondents who met the inclusion criteria. Data were collected using the Modified Morisky Adherence Scale (MMAS-8). Results: The results showed that adherence among participants was high (23.3\%), moderate (56.1\%), and low (20.0\%). Respondent adherence was associated with the role of health workers in monitoring drug therapy. Non-adherence was several factors, including side effects of the drug, complex drug regimens, and ageing.
\end{abstract}

\section{Introduction}

Hypertension is a non-communicable disease (NCD, not caused by microorganisms such as bacteria, fungi, viruses, and protozoa) that has a high prevalence in Indonesia. Weak control of risk factors affects the increase in cases per year. The results of Health Research (Riskesdas) in 2007, 2013, and 2018 reported an increasing prevalence of NCDs, particularly diabetes, hypertension, stroke, and joint diseases (Kemenkes RI, 2019). Hypertension is the second most prevalent NCD in West Nusa Tenggara after gastrointestinal infections. Visits for hypertensive complaints reached 214,080 in 2018 and 108,127 in 2019, illustrating the high incidence of hypertension in West Nusa Tenggara (Dinas Kesehatan NTB, 2018). In general, patients $\geq 60$ years old can be given pharmacological therapy if systolic blood pressure $\geq 150 \mathrm{mmHg}$ or diastolic blood pressure $\geq 90 \mathrm{mmHg}$. The blood pressure target to be achieved for systolic is $<150 \mathrm{mmHg}$ or diastolic target
< $90 \mathrm{mmHg}$ (Strong Recommended-Grade A) (Muhadi, 2016).

Factors that affect hypertension in elderly respondents include aspects of life and changes in the cardiovascular system. These factors can increase the trigger of hypertension (Isnaini \& Lestari, 2018). High-risk factors and poor control cause a higher incidence of hypertension. The medication adherence of elderly respondents is influenced by several aspects, including family support, health officer support, treatment factors, and respondent knowledge level (Pratama \& Ariastuti, 2016). Adherence is a prerequisite for therapeutic effectiveness and the highest potential for improved hypertension control. Non-adherence to treatment is one of the leading causes of therapeutic failure (Hazwan, 2017).

Mandalika Elderly Social Center is a social service owned by the Province of West Nusa Tenggara. Of the 80 people who live there, 32 have hypertension. This 
study was conducted at the Elderly Social Center to explore medication adherence among hypertensive patients at the Mandalika Mataram NTB Elderly Social Center.

\section{Method}

This descriptive cross-sectional study conducted in May 2019 recruited 30 elderly respondents with hypertension from the Mandalika Elderly Social Center, Mataram, NTB, using nonprobability sampling techniques. The inclusion was criteria were hypertension, non-dementia, age 60-90, and willingness to be interviewed and complete questionnaires. This survey used the MMAS- 8 scale to measure medication adherence among participants. The data analysis was carried out to describe the characteristics of each research variable. The total MMAS-8 score was calculated by summing the answers, and adherence was categorised into 1) high adherence (score of 8); 2) moderate adherence (score of 6-7); and 3) Low adherence (score of 0-5) (KrouselWood et al., 2009; Oliveira-Filho et al., 2012).

\section{Results}

This research described the medication adherence among 30 hypertensive respondents who met the inclusion and exclusion criteria at Mandalika Elderly Social Center in Mataram, West Nusa Tenggara.

\section{Respondents characteristics based on gender}

Gender is one of the factors that influence blood pressure. Women tend to have hypertension more than men. The characteristics of the respondents based on gender can be seen in Table I.

Table I: Respondents characteristics based on gender

\begin{tabular}{lcc}
\hline Gender & $\mathbf{n}$ & $\mathbf{\%}$ \\
\hline Men & 4 & $13 \%$ \\
Women & 26 & $87 \%$ \\
\hline Total & $\mathbf{3 0}$ & $\mathbf{1 0 0 \%}$ \\
\hline
\end{tabular}

In this study, the incidence of hypertension was higher in women $(87 \%)$, while it was $13 \%$ in men, suggesting that women are at higher risk of hypertension.

\section{Respondents characteristics based on age}

The characteristics of the respondents based on age can be seen in Table II.

Table II: Respondents characteristics based on age

\begin{tabular}{ccc}
\hline Age & $\mathbf{n}$ & $\mathbf{\%}$ \\
\hline $60-74$ years & 11 & $37 \%$ \\
$75-90$ years & 19 & $63 \%$ \\
\hline Total & 30 & $100 \%$ \\
\hline
\end{tabular}

In this study, participants aged $75-90$ years old were at higher risk of hypertension (63\%) compared to those 60-74 years, indicating that older age increases the incidence of hypertension.

\section{Respondents characteristics based on hypertension duration}

The characteristics of the respondents based on the hypertension duration can be seen in Table III.

Table III: Respondents characteristics based on hypertension duration

\begin{tabular}{ccc}
\hline $\begin{array}{c}\text { Hypertension } \\
\text { duration }\end{array}$ & $\mathbf{n}$ & \% \\
\hline$>5$ years & 13 & $43 \%$ \\
$<5$ years & 17 & $56 \%$ \\
\hline Total & 30 & $100 \%$ \\
\hline
\end{tabular}

Of all respondents in this study, 56\% were diagnosed with hypertension less than five years ago, and $43 \%$ were hypertensive since more than five years ago, indicating a higher proportion of respondents with hypertension since less than five years.

\section{Medication adherence in respondents}

Figure 1 shows medication adherence in respondents.

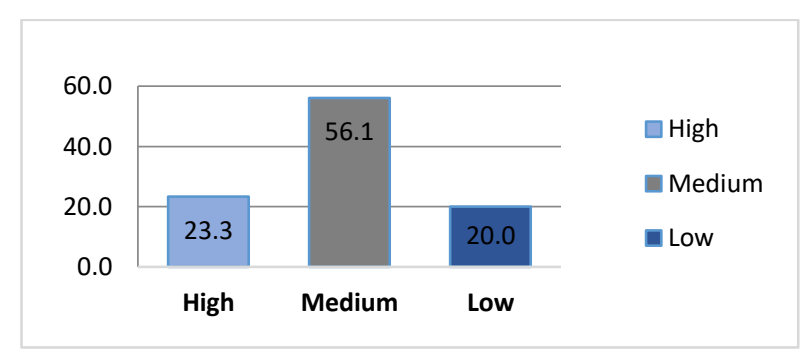

Figure 1: Medication adherence 
The results showed three levels of medication adherence: high (23.3\%), medium (56.1\%), and low $(20.0 \%)$, indicating that the highest percentage of respondents had medium medication adherence. This result is influenced by several aspects, such as health support, family support, attitudes, and age, in line with previous findings suggesting that knowledge, attitudes, and family support affect the hypertensive diet (Tarigan et al., 2018).

\section{Discussion}

This study aimed to explore the characteristics of elderly hypertensive patients associated with medication adherence, namely, gender, age, and disease duration. Based on Table I, gender may lead to differences in the incidence of hypertension, higher among women, consistent with the findings of Anwar et al. (2019). After menopause, hormonal changes occur, such as a decrease in the ratio of estrogen and androgens, which causes an increase in renin, thus triggering an increase in blood pressure. Renin is an enzyme with a small protein released by the kidneys when arterial pressure drops very low. According to Klabunde (2005), the release of renin can be caused by the activation of the sympathetic nerves (activation via $\beta 1$-adrenoceptor), decreased renal artery pressure (due to low systemic pressure or renal artery stenosis), and reduced salt intake to the distal tubule. Ageing is directly proportional to high blood pressure because, alongside ageing, structural and functional changes occur in the peripheral vascular system, responsible for controlling blood pressure. These changes include atherosclerosis, loss of elasticity of the connective tissue, and decreased ability of smooth muscle relaxation of blood vessels, which, in turn, reduces the ability of blood vessels to strain and stretch (Suzanne et al., 2013).

Respondents have been experiencing hypertension for more than a year, as shown in Table II, so they understand the importance of taking the medication regularly and controlling blood pressure through an elderly Posyandu visit card once a month. Respondents may also be aware of risks and complications if they do not comply with their medication. The percentage of hypertensive respondents for less than five years is much higher than that of those over five years, in line with the findings of Anwar et al. (2019), showing that the distribution of hypertensive respondents for the period of $1-5$ years is $57 \%$.

Based on Figure 1, the adherence of most hypertensive respondents at Mandalika Elderly Social Center in NTB fell into the moderate category, i.e., 17 respondents
(56.1\%), followed by those with low (6 respondents, $20.0 \%$ ) and high (7 respondents, $23.3 \%$ ) adherence, indicating that elderly respondents need supervision or assistance from the healthcare professionals at the centre due to ageing and memory loss. This result is consistent with previous findings showing moderate adherence among elderly respondents in the working area of Puskesmas Air Putih Samarinda (41.0\%) (Anwar et al., 2019) and 40\% among hypertensive respondents at the Wirobrajan Health Center Yogyakarta in August 2016 (Cahyani, 2018).

Medication adherence is essential to help respondents recover quickly from their illness (Sulistyarini \& Hapsari, 2015). Side effects and type of drug are among the factors that affect adherence to medications. A complex therapeutic regimen will lower adherence rates (Lam et al., 2007). Non-adherence leads to increased hospitalization length and risk of death. Some of the solutions include assessing the respondent's therapeutic needs, simplifying the therapeutic regimen, using long-acting medications, and supporting families and health workers (Burnier et al., 2020). Medication adherence in elderly respondents is explained by the role of the family and health workers, in addition to excellent self-motivation. Improved compliance can be achieved by providing one-dose therapy and using a drug box for single-dose in elderly respondents.

\section{Conclusion}

The results showed that adherence among participants was high (23.3\%), moderate (56.1\%), and low (20.0\%). Respondent adherence was associated with the role of health workers in monitoring drug therapy. Nonadherence was several factors, including side effects of the drug, complex drug regimens, and ageing.

\section{Acknowledgements}

The authors would like to thank all the research participants at the University of Muhammadiyah Mataram, Indonesia.

\section{References}

Anwar, K., Masnina, R. (2019). Hubungan Kepatuhan Minum Obat Antihipertensi denganTekanan Darah Pada Lansia Penderita Hipertensi di Wilayah Kerja Puskesmas Air Putih Samarinda. Borneo Student Research, 1568, 494-501 
Burnier, M., Polychronopoulou, E., \& Wuerzner, G. (2020). Hypertension and Drug Adherence in the Elderly. Frontiers in Cardiovascular Medicine, 7, 1-9. https://doi.org/10.3389/fcvm.2020.00049

Cahyani, F. M. (2018). Hubungan Kepatuhan Minum Obat Antihipertensi Terhadap Tercapainya Target Terapi Pasien Hipertensi di Puskesmas Wirobrajan Yogyakarta. Journal of Pharmaceutical Science and Medical Research, 1(2), 10. https://doi.org/10.25273/pharmed.v1i2.2981

Dinas Kesehatan NTB. (2018). Profil Kesehatan Provinsi Nusa Tenggara Barat Tahun 2017. Provinsi Nusa Tenggara Barat Tahun 2017, 1-85

Hazwan, A. (2017). Gambaran Karakteristik Penderita Hipertensi dan Tingkat Kepatuhan Minum Obat di Wilayah Kerja Puskesmas Kintamani I. Intisari Sains Medis, 8(2), 130134. https://doi.org/10.1556/ism.v8i2.127

Isnaini, N., \& Lestari, I. G. (2018). Pengaruh Self Management Terhadap Tekanan Darah Lansia Yang Mengalami Hipertensi. Indonesian Journal for Health Sciences, 2(1), 7-18. https://doi.org/10.24269/ijhs.v2i1.2018

Kemenkes RI. (2019). Profil Kesehatan Indonesia Tahun 2019. In Kementrian Kesehatan Repoblik Indonesia (Vol. 42, Issue 4)

Klabunde, R. E. (2005). Cardiovascular Physiology Concepts (B. Sun \& C. Taylor (eds.)). Lippicontt Williams and Wilkinks

Krousel-Wood, M., Islam, T., Webber, L. S., Re, R. N., Morisky, D. E., \& Muntner, P. (2009). New medication adherence scale versus pharmacy fill rates in seniors with hypertension. American Journal of Managed Care, 15(1), 59-66

Lam, P. W., Lum, C. M., \& Leung, M. F. (2007). Drug nonadherence and associated risk factors among Chinese geriatric respondents in Hong Kong. Hong Kong Medical Journal, 13(4), 284-292

Muhadi. (2016). JNC 8: Evidence-based Guideline Penanganan Pasien Hipertensi Dewasa. Cermin Dunia Kedokteran, 43(1), 54-59

Oliveira-Filho, A. D., Barreto-Filho, J. A., Neves, S. J. F., \& de Lyra, D. P. (2012). Association between the 8-item Morisky Medication adherence Scale (MMAS-8) and blood pressure control. Arquivos Brasileiros de Cardiologia, 99(1), 649-658. https://doi.org/10.1590/S0066-782X2012005000053

Pratama, G., \& Ariastuti, N. (2016). Faktor - Faktor Yang Mempengaruhi Kepatuhan Pengobatan Hipertensi Pada Lansia Binaan Puskesmas Klungkung 1. E-Jurnal Medika Udayana, 5(1)

Sulistyarini, T., \& Hapsari, M. F. (2015). Delapan Faktor Penting yang Mempengaruhi Motivasi Kepatuhan Minum Obat Pasien Hipertensi. Jurnal Stikes, 8(1), 11-22

Suzanne, Smeltzer, \& Bare, B. G. (2013). Buku Ajar Keperawatan Medical Bedah Volume 2- Brunner dan Suddath. EGC

Tarigan, A. R., Lubis, Z., \& Syarifah, S. (2018). Pengaruh Pengetahuan, Sikap Dan Dukungan Keluarga Terhadap Diet Hipertensi Di Desa Hulu Kecamatan Pancur Batu Tahun 2016. Jurnal Kesehatan, 11(1), 9-17. https://doi.org/10.24252/kesehatan.v11i1.5107 